\title{
Vocational Education and Training Labor Development Policies and Strategies Support the Industrial Revolution
}

\author{
Pengpith Tvenpusa \\ Rajamangala University of Technology Thanyaburi \\ Faculty of Education Maha Chulalongkornrajavittayalai University
}

\begin{abstract}
Research papers on Vocational Education and Training Workforce Development Policy and Strategy to Support industrial revolution due to Disruptive Technology aim to explore directions, trends, impacts, as well as policies for managing labor issues in the Disruptive Technologies era, studying the opinions of executives of businesses used or affected by Disruptive Technology, as well as obstacles, feedback, focusing on issues, concepts about Disruptive Technologies and vocational education concepts. Technical Vocational Education and Training (TVET) using qualitative research methodology and procedures for conducting studies. The study results are the impact of Disruptive Technology on Thai workers and technical vocational education and training (TVET) to develop Thai people during disruptive technology, educational management to develop Thai people in the Thai era.4.0 Therefore, two focuses must be placed on: 1) increasing labor skills and 2) educating to create new workers under reality. Realistic work means workers with flexible knowledge and skills and adapting to advanced technologies. Therefore, for work to meet the required standards, TVET development requires a professional standardization process, namely information related to work knowledge. Creating the necessary skills and attributes requires operational standards. Procedures and scope of operation Operational Equipment Proof of performance and expertise in technical skills Knowledge, competence, and performance results and policy recommendations on the government sector. Private Educational Institutions in managing labor issues in the Disruptive Technology era.
\end{abstract}

Keywords: Disruptive Technology, TVET, Vocational Education

\section{Introduction}

Over the next 15 years, it is estimated that $14 \%$ ofthe work force is at high risk of being replaced by automation, and another $30 \%$ changes in skills used in the workforce. Many countries worldwide have struggled to create young people and working - class people with work skills and life skills high enough for disruptive technology. Linked to changes in work and employment, Disruptive Technology is a term that describes the large - scale changes that have occurred from modern technology of robotics and automation (Hynes, Elwell \& Zolkiewski 2016). It will have an immediate and severe impact on careers and work skills, a crucial part of the fourth industrial revolution.

In Joseph Bower and Clayton Christensen's article "Disruptive technology: catch the wave, " he said that some new technologies could destroy or change the order of existing market domination or even create new markets (Bower \& Christensen 1995). Furthermore, in 1997, Clayton M. Christensen said that the model of technological development, Sustaining Technology, was a gradual improvement. Disruptive technology, a new storm, may initially be incomplete but can improve rapidly and efficiently beyond mainstream technology. Technology forecasters have identified a group of disruptive technology, artificial intelligence, 3D printing, advanced materials, and nanotechnology that create and expand each other, affecting socioeconomic, political, geographic, and population factors (Manyika et al.2013; World Economic Forum 2016).

National Economic and Social Development Board (NEC) Information Specify the quarter unemployment rate.3 (2017) at $1.2 \%$, or 450,000 unemployed, $0.9 \%$ higher than the same period last year, $1 \%$ or 400,000 above the standard threshold. The use of industrial machinery is increasing, but the use of the industry is in line with the government's Thailand 4.0 policy, and the industry needs to use machinery in part because Thailand is moving into an aging society. The proportion of older people now reaches $10 \%$ of the population of 67 million, and in the future, it will increase to $20 \%$, so the industry must prepare for production processes in line with people of working age due to lower birth rates.

For Thailand, "Thai People's Development 4.0" is the most critical factor driving the country from middle - income trap countries to high - income countries. The ideal educational arrangement for the development of Thai people 4.0 is TVET education and training, which is recognized worldwide for its role in preparing people to participate in the creation of work values and critical sources of the workforce and skilled workforces, and critical skills in the 21 centuries for TVET learners including 1) Science, Technology, Engineering, Mathematics (STEM), 2) problem - solving, and 3) 4C's (critical thinking). Communication, collaboration, and creativity.

This study aims to explore directions, trends, impacts, and policies for managing labor issues in the Disruptive Technologies era, studying the executive's opinions of businesses used or affected by Disruptive Technology, obstacles and feedback, and other issues. 


\section{Literature Review}

The concepts and theories involved in this research consist of two parts: 1) concepts about Disruptive Technologies and effects 2) concepts on Technical Vocational Education and Training (TVET)

\section{Concepts about Disruptive Technologies and effects}

Disruptive technology refers to innovations or technologies that are used to create markets and value products that apply technology and severely impact the market of existing products, as well as potentially causing businesses that use traditional technologies to be knocked down or closed, unlike conventional innovations that Nama uses for efficiency - enhancing purposes. Increase product quality or reduce traditional route costs only. In its report, the McKinsey Global Institute identified 12 technologies that would influence global change:

1) Mobile Internet is a tool that uses Internet technology to connect with the world, such as mobile banking, which is an Internet financial transaction.

2) Automation of Knowledge Work is a technology or intelligent and intelligent software used to diagnose diseases to achieve accuracy or use in legal analysis.

3) The Internet of Things implants smallest to smallest sensors to transmit communications, which can be used, such as recognizing the quality of the soil from sensors sprinkled in the soil, knowing which crops should be grown with the best yield.

4) Cloud computing is a data storage technology and software integrated to use that enables small businesses to compete with large businesses without investing in a high computer.

5) Advanced robotics technology is used in surgery to minimize patients' impact and accurate surgical outcomes.

6) Autonomous vehicles are technologies that are substituted in agricultural or forestry exploration, as well as military.

7) Next - Generation Genomics is an improved technology that develops genes to treat diseases.

8) Next - generation storage is the creation of Fuel Cells for use in electric vehicles and Highbridge.

9) 3D Printing technology is a $3 D$ printing system that reduces the cost of production of goods by being used in dental and medical applications.

10) Advanced Materials technology is always the production of new materials such as self - cleaning materials. Ultra - strong and light, etc.

11) Advanced Oil - Gas Exploration and Recovery is a technology that advances in pioneering oil and gas mining. This makes it more oil and gas.

12) Renewable Electricity Technology: The Technology generates electricity from sources that never end, such as sunlight, wind, waves, hot springs, etc.

\section{Effects of Disruptive Technology}

Christensen and Rayno (2003) classified the technology into two categories: sustaining technologies, a technology focused on improving the efficiency of products in traditional mechanical systems. The other type of technology is called Disruptive technologies, which develop products/services to have new systems and new looks cheaper. Disruptive technology may or may not be the latest technology, perhaps an existing one. However, there are changes in specific market elements, such as quality, production process efficiency, cost, or price, making these technologies the right conditions desirable to become popular with the market.

\section{Concept about Vocational Education Educational \& Training Techniques (TVET)}

The relevant concepts and theories in this section include 1) meaning, vocational education, educational techniques and training (TVET), and 2) the skills required for TVET in the 21 century as follows: Technical Vocational Education and Training (TVET) is recognized worldwide for its role in preparing people to participate in creating work value and skilled sources of the workforce. According to a 2001 joint publication by the United Nations Educational, Scientific and Cultural Organization (UNESCO) and the International Labour Organization (ILO) on Vocational Education and Technical Studies and Training for the 21 Century, TVET is defined as 1) as an essential component of the ordinary line, 2) prepares people into the profession and the world of work effectively. Uwameiye \& Uddin, 2017). Similarly, UNESCO (2009) defines TVET as public and private educational institutions in many forms. Formal or informal education is intended to provide all community members with access to this learning path throughout their lives.

From the above definition, TVET aims to eliminate ignorance. Increase knowledge, develop skills, and cultivate the attitudes necessary to enter the profession and advance (Kukoyi, 2009), in line with the concept of Instrumental Sornil and faculty (2005), explaining that TVET's goal is to develop people to their full potential. With the environment in mind, Empower people for sustainable development, provide lifelong education, have professional qualifications, manage open and flexible learning. Certified and compared to transfer experience, high priority to vocational education by designating it as a national agenda. Investment reforms have been implemented in line with the development plan. There are benchmarks for indicators in quality management; there is a link between different studies. Continuing education and work Use performance - based learning with the core skills, skills needed for lifestyle. Personnel must have the right qualifications, quality, and qualifications, with continuous improvements for the status of graduates and professional workers to be comparable to other professional fields.

M. Reeve (2016) wroteanarticletitled21st - century skills students need in technical and vocational education and training (TVET21). Furthermore, develop teaching and learning based on current educational concepts and practices. It also means providing the critical skills needed in the 21century, critical skills in the 21century for TVET learners, and guiding how to build these skills in TVET programs, including science, Technology, engineering, mathematics (STEM), problem - solving, and4C's (critical thinking, communication, collaboration, and creativity), which are consistent with the concepts in Valerie Pong Prabhyai's article (2017). The necessary 21 skills of technical and vocational education learners in Thailand, the 
management of technical and vocational education in Thailand.

Those involved need to provide students with core knowledge and key skills of the 21century: 1) STEM skills, 2) problem - solving skills, and3) 4C'sskills.

\section{Research Methods}

In conducting a study on the policies and management of labor problems in the Disruptive Technology era by the overall formulation of research methodology or methodology introduced in this study, the study authors established the qualitative research methodology. The summary is as follows:

Documentary research: For determining the methodology by using qualitative research processes with documentary research procedures, the study participants initially conducted the study process following the methodology by using qualitative research processes to study and analyze data from documentary research by reviewing relevant concepts, theories, and literature.

In - depth interview: Methodology is defined by using structured interviews as interviews using all the same questions, an open - ended interview, a flexible and open methodology process.

Populations and Samples: The target audience is executives who play a role in shaping the country's labor policies. The key informant interview method to be interviewed, explicitly assigning respondents because respondents are targeted to suit the needs of the study participants, who are called "important informants", who are executives who play a role in shaping state policies related to the production and labor. Business units using Disruptive Technology of 26 people in Thailand.

Qualitative information obtained through interview research and documents is analyzed and processed by linking relationships in various factual terms. Both logically and effectively, in which the analysis is released in the manner of depiction, leads to answers in the study and is summarized academically, accompanying the report's writing. To point out the business operator's perspective on the skills needed to spread the associated Disruptive Technologies. In Thailand 4.0 and the skills needed for students, students, labor, technical, vocational education and training (TVET), in Disruptive Technologies, develop policies to prepare future workers for these businesses.

\section{Result and Discussions}

The Industrial 4.0 era results from disruptive technologies transforming traditional global economic mechanisms based on innovation and modern technology add value and revenue to the industries. It is necessary to restructure the workforce to be ready and enhance applying and using modern technology. The study results will focus on disruptive technology's impact on Thai workers and technical career education and training (TVET) to develop Thai people in the Disruptive Technology era.
Impact of Disruptive Technology on Thai workers.

Disruptive technologies are a technology that is progressive and can change the lifestyle. In its report, the McKinsey Global Institute identified 12 technologies that will influence global change: 1. Wireless Internet 2. Automated Technology in analytics 3. Internet of Things 4. Cloud Computing 5. Robotics technology 6. Drone or semi driverless vehicles 7. Biotechnology (genomics) 8. Equipment or energy storage systems 9.3D printing technology 10. SMART material technology 11. Exploration and oil drilling technology 11. Exploration and oil drilling technology 12. Renewable Energy Technology

Global Institute also estimates that the use of these 12 technologies can have an economic impact. In 2025, the estimate is not just agues but an in - depth analysis of critical applications and can generate value in many ways, including consumer surplus demand. (consumer surplus), as a result of better products, cheaper, and cleaner environment

Many research agencies predict the trend towards modern technology, both automation. AiIoT (Internet of Things) robots are widely used in the production of goods, services, and everyday life, whether to replace or even take over the labor market. The OECD (2018) estimates that over the next 15years, $14 \%$ of workers are at high risk of being replaced by automation, and $30 \%$ face significant changes in the skills they use. In addition, many countries world wide have experienced the problem of not creating young people and working - class people with work skills and life skills high enough to face disruptive technology.

According to Tanad Kaewcharoenpaisan's (2017) research, the S Curve 4.0 ecosystem's workforce strategy is 60 percent and 70 percent by 2022. The software, technology, and IT industries will be the biggest hits, second only to Bio Technology and retail, engineering, and construction. The energy industry, gas, oil, petrochemical, and electricity, is less affected. The researchers estimated the workforce to be disrupted between 2018 and 2021, estimating the impact on the workforce that requires the provision or restructuring of work skills to support Disruptive Technologies at 50 percent as follows: 1) Modern vehicles are 400, 000, 2) intelligent electronics, 23, 177 people, 3) good income group travel and health tourism.3, 079, 342 4) Agriculture and biotechnology 1, 247, 845, 5) Food processing, 1, 494, 985, and promotion in the new S Curve industry include 6) Robots, 101, 482, 7) Aviation and logistics, 103, 001, 8) biofuels and biochemistry.3, 796 people 9) Digital 11, 576 (10) Comprehensive Medical Total 6, 509, 264

\section{Career Education and Training (TVET) to develop Thai} people in disruptive technology.

Education management for Thai people development In Thailand 4.0, there must be two emphasizes 1) increasing labor skills and 2) educating to create new workers following reality. Technical Vocational Education and Training (TVET) is recognized worldwide for its role in preparing people to create work value and skilled sources of the workforce. According to a 2001 joint publication by the United Nations Educational, Scientific and Cultural Organization (UNESCO) and the International Labour 
Organization (ILO) on Vocational Education and Technical Studies and Training for the 21 Century, it defines TVET as 1) as an essential component of the ordinary line, 2) as a way to effectively prepare people into the profession and the world of work. Similarly, UNESCO (2009) defined TVET in many forms as public and private educational institutions. Formal or informal education is intended to provide all community members with access to this learning path throughout their lives.

M. Reeve (2016) wrote an article titled 21st - century skills students need in technical and vocational education and training (TVET21). Furthermore, develop teaching and learning based on current educational concepts and practices. It also means providing the critical skills needed in the 21century, critical skills in the 21 century for TVET learners, and guiding how to build these skills in TVET programs, including science, technology, engineering, mathematics (STEM), problem - solving, and4C's (critical thinking, communication, collaboration, and creativity), which are consistent with the concepts in Valerie Pong Prabhyai's article (2017). The necessary 21skills of technical and vocational education learners in Thailand, the management of technical and vocational education in Thailand. Those involved need to provide students with core knowledge and key skills of the 21century: 1) STEM skills, 2) problem - solving skills, and3) 4C'sskills.

STEM Education is an educational approach that integrates knowledge between subjects such as scientific knowledge, technological knowledge, engineering knowledge, and mathematical knowledge. S-Science is a subject on the study of phenomena. In nature, based on the scientific inquiry process. $\mathrm{T}-\mathrm{Technology}$ is a subject that applies other related fields of work to solve problems. Improve, modify or develop things to meet human needs or necessities. E - Engineering is a subject that is about innovating or creating things to facilitate humans. Based on knowledge of Science, Mathematics, and technological processes, apply them to create pieces. $\mathrm{M}$ - Mathematics is a subject that studies computational or computational subjects that are fundamental to the study and further engineering.

Creative Problem Solving refers to the process of finding answers and solving problems, as well as improving the status quo. Collaboration between creativity and critical thinking Creativity can be done by thinking as profoundly and variedly as possible without judging ideas as good or not, until a certain point considering them with judgment. To choose and evaluate the solution until the best solution is made. Plan solutions and solve problems by believing that they can solve problems and control themselves to solve problems with prudence and completeness. Assemble five steps as follows

Step 1: Accessing problems is to understand, get to know the situation in question. It is carefully studied in detail to identify problems that need to be addressed. Explore data from data sources - the framework for solving the problem. Step 2: To come up with a solution is to use creativity to find as many solutions as possible. It is not judged whether the idea is wrong or based on the amount of thinking necessary for solving the problem, including creating a new solution from the original method.

Step 3: Selecting and preparing is to evaluate the solution with the criteria that are created to the best choice. Then consider the support and potential obstacles in the rescheduling and planning process.

Step 4: Problem planning is problem planning, guaranteeing the feasibility of a solution. Monitor, track, improve the activities used to solve problems. Plan solutions using a person's abilities and limitations Context, conditions, resources, and obstacles, whose steps are 1) Resource evaluation, are identifying the guidelines and resources required to solve problems.

Step 5: Take action: Put the plan into action. Directing and tracking solutions Compared to the result or target set. Problem - solving behavior is observed and recorded. When as planned, it provides self - reinforcement.

Skills and four innovations are teaching styles that stimulate students' self - learning, which will be the critical skills of people in the 21 century. Critical thinking solves problems. Communication is one of the top skills the new world is looking for. Academic knowledge is essential as a base for in - depth expertise, but cognitive (creative, analytical) and socializing skills with others (working, communicating with others) or 4Cs skills are bridges to the real world of $4 \mathrm{Cs}$ or four areas of learning and innovation skills:

1) Creativity and innovation think outside the box and build on it.

2) Critical Thinking and Problem - Solving think critically and solve problems themselves.

3) Communication communicates properly.

4) Collaboration, collaboration with others

Summary of Education Management for Thai People Development In Thailand 4.0, there must be two emphases: 1) increasing labor skills and 2) educating to create new workers following reality. Realistic work means workers with flexible knowledge and skills and adapting to advanced technologies. Therefore, for work to meet the required standards, TVET development requires a professional standardization process, namely information related to work knowledge. Creating the necessary skills and attributes requires operational standards. Procedures and scope of operation Operational Equipment Proof of performance and expertise in technical skills knowledge, necessary competence and performance results, etc.

According to interviews with target audiences, executives shape state policies related to production and labor. The 26 business entities that operate Disruptive technology concluded that 1) the business agency provides technology workers with the following qualifications to determine the following qualifications in time. Use technology as language skills. Manage data, improve yourself regularly.2) Skills of employees that the sector needs: technology skills, adaptation skills, quick learning skills, emotional intelligence, and 3) ways to improve employee skills: develop to learn, understand and use technology at a basic level, focus on creating an experience for employees by providing training in departments or sending training in 
educational institutions or training institutions, and bringing talent, digital generations to the organization.

The general policy should support and directs what is expected. Do not discourage fear of disruption. Appropriate and flexible regulatory and legal policies and promote the country's ability to innovate or technology. At the same time, there must be a proactive policy. If new technologies change the skill characteristics of the labor market by promoting technical career education and training (TVET) courses at both school and university level, flexible and adaptable. It can increase the learning opportunities of workers at work and throughout life.

\section{Conclusion and Suggestions}

Policy recommendations on the part of government and educational institutions for managing labor issues in the Disruptive Technology era

1) Integrating and collaboration between Ministry of Labour, Ministry of Higher Education, Science, Research and Innovation, Ministry of Education, and Ministry of Industry.

2) In terms of data to get the data to work in the same direction. In the country's technology and innovation, such as Artificial Intelligence: AI, Machine Learning, etc. The collection of data of all relevant agencies following Article 1. To create a database and utilize the data to manage big data, such as the number of workers that must be produced should be in line with the needs of the labor market in order to achieve maximum efficiency. Increase the number of workers and reduce the unemployment of the number of domestic workers.

3) Establish standards, adjust attitudes, perspectives and change values in Thai society to accept professional skills rather than focus on diplomas, focusing on graduating professions, having a job or being able to be independent.

4) A clear and concrete national strategy and a plan for developing technology and innovation must be defined. Such as Artificial Intelligence: AI, Machine Learning, etc. for both short - term and long - term plans $(5-10$ years) Clearly ahead, while providing ongoing budget support.

5) It must raise awareness and awareness for people in the country, both in the private sector. The social sector and the general public have focused on the consequences of technology and innovation.

6) Promoting and supporting scholarships in technology and innovation such as basic technology in 4 areas: 1) Biotechnology 2) Nanotechnology 3) Material Science Technology Energy \& Environment 4) Communication and digital information technology.

7) Government agencies such as the Department of Skill Development set standards, the Ministry of Labour should set and adjust the guidelines for training and development, focusing on 12 new technological and innovative skills to meet the needs of the workplace's workforce.

8) Students' production of educational institutions under the Ministry of Higher Education, Science, Research and Innovation and the Ministry of Education should adjust the teaching curriculum to meet the needs of the market demand to meet the needs of the labor market sector.

9) The government should invest in opening a training center for speakers. Teachers with knowledge and expertise, including those at the center, must - have equipment. Advanced technology and increased access to the skills training of modern technology by providing a large and adequate number in all country regions.

10) Force and welfare are configured to motivate professionals in such professions. Work with educational institutions in teaching and research to develop new personnel and innovations in the country.

11) The government should focus on the national agenda for developing and raising awareness for the country's people in technology and innovation.

\section{Acknowledgement}

The author would like to thank all informants and qualified persons interviewed for information and participants in the Higher Certificate Program in Public Policy Management and Public Law. Class 18 The King Prajadhipok's Institute has been involved in coordinating information collection and compiled this article.

\section{References}

[1] Abernathy, WJ \& Utterback, JM (1978). Patterns of industrial innovation, Technology Review, vol.64, no.7, pp. 254 - 28.

[2] Asian Productivity Organisation (APO) (2018), APO Productivity. Data book.

[3] Bower, J \& Christensen, C (1995). Disruptive technologies: catching the wave, Harvard Business Review, vol.73, no.1, pp.43 - 53

[4] Christensen, CM \& Raynor, M (2003). The innovators solution: creating and sustaining Successful growth, Harvard Business School Press, Boston, Mass.

[5] Clayton, B, Jonas, P, Harding, R, Harris, M \& Toze, $M$ (2003). Industry currency and Professional obsolescence: what can industry tell us, NCVER, Adelaide, SA.

[6] Danneels, E (2004). Disruptive technology reconsidered: a critique and research agenda. Journal of Product Innovation Management, vol.21, no.4, pp. 246 - 58 .

[7] Hynes, N, Elwell, AD \&Zolkiewski, J (2016). The role of inter - organizational networks in enabling or delaying disruptive innovation: a case study of mVoIP', Journal of Business \& Industrial Marketing, vol.31, no.6.

[8] International Labor Organization (ILO) (2016), ASEAN in Transformation: How technologyis changing jobs and enterprises. available at https: //unctad. org/meetings/en/Presentation/cstd2016_p24_Jae HeeChang_ILO_en.pdf.

[9] Kukoyi, D. (2009). Design and implementation of Public - Private Partnerships in Education. Case study of Technical and Vocational Education. 
[10] Manyika, J, Chui, M, Bughin, J, Dobbs, R, Bisson, P \& Marrs, A (2013), Disruptive technologies: advances that will transform life. Business, and the global economy, vol.12, McKinsey Global Institute San Francisco, CA.

[11] Markides, C (2006). Disruptive innovation: in need of better theory, Journal of Product Innovation Management, vol.23, no.1, pp.19- 25.

[12] Nagy, D, Schuessler, J \& Dubinsky, A (2016). Defining and identifying disruptive innovations. Industrial Marketing Management, vol.57, pp.119 26.

[13] OECD (2018). Transformative Technologies and Jobs of the Future. Background Report for the Canadian G7 Innovation Ministers' Meeting, Montreal, Canada, 27 - 28 March 2018

[14] Oviawe, J. I., Uwameiye, R. \& Uddin, P. S. O. (2017). Bridging skill gap to meet Technical, Vocational Education and Training school workplace collaboration in the 21 st century. International Journal of vocational education and training research.3 (1), 7 - 14.

[15] Reeve, E. M. (2016).21st century skills needed by students in technical and vocational education and training (TVET). Asian International Journal of Social Sciences, 16 (4), $62-74$.

[16] Tellis, GJ (2006). Disruptive technology or visionary Leadership, Journal of Product Innovation Management, vol.23, no.1, pp.34 - 8.

[17] World Bank (2016). World Development Report 2016: Digital Dividends, Washington, DC: World Bank.

[18] World Economic Forum (2016). The future of jobs, World Economic Forum.

[19] World Economic Forum (2018), The Future of Jobs Report 2018. Insight Report, Centre for the New Economy and Society.

[20] Nattapong (2016). Teaching and learning based on Creative Problem Solving Process. SDU Research Journal Humanities and Social Sciences Vol.12 No.3 September - December 2016 Instrumental,

[21] Sornil and faculty. Vocational Education and Technology Research Report.

[22] Thammawongsa (19October2018).4CS: Four learning skills that should be practiced and without talent. Searched from: https: //thepotential. org/2018/10/19/4cs - for - 21st - century - learning/

[23] Parramaticale Wimonsiri. The 20 - Year National Strategy (2017 - 203 https: //www.thaigov. go. th/news/contents/details/10473 6).

[24] Siripatrachai Pornthip (2013). STEM Education with Skills Development in the 21 Century. Page 49 $-56$.

[25] SriltdhamSaranit. Universities adapt to edible research aimed at national innovation center. Post Today 20 Oct 2018 Searched 10 June 2019, from https: //www.posttoday. com/social/general/568252

[26] SuebpongPrabhayai.21 Century Skills Required of Technical and Vocational Education Learners in Thailand. Journal of Industrial Education Page 207 213.

[27] Vocational Education and Training Workforce Development Policy and Strategy to Support industrial revolution due to Disruptive Technology.

[28] Technical Vocational Education and Training (TVET) Development Policy to Support industrial revolution due to Disruptive Technology in Developing Country. 